\title{
Investigation of Influence of Injector Opening Pressure and Nozzle Geometry on the Performance and Emission Characteristics of DI Diesel Engine with CAOME
}

\author{
Varun Kumar Reddy N 1,2, S. G. Sangashetty ${ }^{3}$, Nagaraj Ramalingayya Banapurmath ${ }^{*}$ \\ 1 Assistant Professor, REV A University, INDIA \\ ${ }^{2}$ Research Scholar, Department of Mechanical Engineering, RRCE, Bangalore, INDIA \\ ${ }^{3}$ Professor, Rajarajeshswari College of Engineering, Bengaluru, VTU, INDIA \\ ${ }^{4}$ B.V.B. College of Engineering and Technology, INDIA
}

*Corresponding Author: nrbanapurmath@gmail.com

Citation: Reddy N, V. K., Sangashetty, S. G. and Banapurmath, N. R. (2019). Investigation of Influence of Injector Opening Pressure and Nozzle Geometry on the Performance and Emission Characteristics of DI Diesel Engine with CAOME. European Journal of Sustainable Development Research, 3(4), em0093. https:// doi.org/10.29333/ejosdr/5787

Published: May 29, 2019

\begin{abstract}
The diminution of fossil fuels and stringent pollution norms obliging researchers to search for fuels that result in less pollution and the one that suits to power compressed ignition engines. In the current work the effect IOP (Injector opening pressure) and nozzle geometry on the performance and emission characteristics of diesel engine fueled by Castor oil methyl esters (CAOME) is reported. For a 5-hole nozzle at $240 \mathrm{bar}$ IOP the highest brake power is obtained (27.32\%). Peak pressure gradual upturn was observed when the IOP was varied from $210 \mathrm{bar}$ to $240 \mathrm{bar}$ and the peak value of pressure is 79 bar at IOP of 240 bar.
\end{abstract}

Keywords: inject opening pressure, injection timing, castor oil methyl esters

\section{INTRODUCTION}

The progress of any country mainly be influenced by on the available energy resources. With ever increase in energy consumption, rigorous pollution norms and depletion of fossil fuels resulted in need for huge investment in energy sector to fulfill the requirement and to investigate new sources of ecofriendly energy resources. Energy is the vital factor that decides the socio-economic growth of human society. Mechanization and modernization resulted in abrupt rise in energy demand and henceforth the exploration of the same which are mainly fossil fuel based. This situation resulted in search for new alternatives and one among them is oils obtained from green matter. Oils obtained from sunflower, soybean, cottonseed, canola, jatropha, corn, peanut oil etc. are in comparison with petroleum based fuels. These oils can be used in diesel engines with several modifications such as preheating to decrease viscosity, Varying IOP and injection timing.

\section{First-generation Biofuels}

Ethanol synthesized by fermenting sugar extracted from sugar, sugar beets, sugar extracts from starch that present in maize kernels and other feedstock are considered as first generation biofuel. The process utilizes different organisms that can yields alcohol and butanol. Fuel ethanol production in the year 2017 was led by United States with 15800 million gallons followed by Brazil with 7060 million gallons and European Union with 1415 
million gallons. The trend of bio ethanol production in India is in uptrend and has reached 280 million gallons in the year 2017.

\section{Second-generation Biofuels}

Biofuels that are considered under Second generation are synthesized from ligno cellulosic biomass, facilitating the use of low cost, non-edible feed stocks which limits the conclusion between food and fuel demand. Further the second generation biofuels are classified based on the process used for the conversion of green matter into fuel that may be bio or thermo chemical. Second generation ethanol or butanol are produced by biochemical process whereas thermo chemical process is used for generation of other second generation fuels. The fuels produced by thermo chemical process are not much familiar even they found commercial success which includes dimethyl ether, methanol and Fischer-Tropsch liquids. As we know biomass has found its application as animal fodder, as raw material in fertilizer industry and in paper making. Mammoth magnitudes of farming trashes are generated annually worldwide. Even though biomass has great potential in terms of energy content, large quantities are disposed that has ill effects on environment.

As the energy consumption is increasing and fossil fuels are depleting, the research related to alternative sources to fuel internal combustion (IC) engines has got great potential. Especially the biofuels produced from green matter maintains carbon balance in nature and may replace conventional fuels in the near future. Castor oil is a potential source to produce biodiesel and is suitable to use in IC engines (Arunkumar et al., 2019). A detailed study of the literature relevant to the effect of injection timing (IT) and injection operating (IOP) was also studied.

Panwar et al. (2010), have evaluated the engine Performance when fueled with different blends of CAOME. In this work the biofuel was prepared by transesterification using potassium hydroxide $(\mathrm{KOH})$ as catalyst and properties of CAOME are in comparison with diesel. The engine performance parameters are analyzed with different blends of biodiesel and are in comparison with diesel. Only $2 \%$ difference in calorific value was found between diesel and B10 blend (45.50 MJ/kg). Nitrogen oxide (NOx) emissions for CAOME are similar trend as of diesel at lower loads and found deviation at full loads. Hence CAOME can be used as an alternative fuel in diesel engines. Barajas Forero (2005), has studied the production of castor oil biodiesel by transesterification using $\mathrm{NaOH}$ catalyst and the results prove that it better suits for cold weather operation. Properties of biofuel were tested according to American Society for Testing and Materials (ASTM) D6751 standard and are in comparison with petroleum diesel and B100 being exception due to high viscosity and humidity. The viscosity of mixture increased with increase in proportion of biodiesel but not affected the atomization characteristics.

Imankular (2012), has studied the biodiesel synthesis technique from castor oil and evaluated physical and chemical characteristics of oil including infrared (IR) spectrum. The properties of biodiesel are in comparison with diesel. The value of coking capacity of $10 \%$ the residue was within the limit of norms. The results shows that optimum concentration of addition of the bio additive equal to $5 \%$ of mass. IR spectrum of biodiesel indicates the fluctuation of hydroxyl group of ricinoleic acid which also allows distinguishing it from other fatty acids and castor acid itself forms other natural substances. Okullo et al. (2012) have evaluated physico-chemical properties of biodiesel prepared from jatropha oil and castor oil. In this study castor oil biodiesel was produced in the presence of methanol and sodium hydroxide $(\mathrm{NaOH})$ catalyst. The evaluation of physico- chemical properties of castor oil are significant because of the presence of exceptionally high ricinoleic acid. The low temperature suitability (Barajas Forero, 2005) and its ability for complete solubility in alcohol (Imankulov, 2012) makes it suitable for biodiesel production. Study reveals that biodiesel derived from jatropha oil suits its usage in diesel engine whereas biodiesel produced from castor oil (B100) is not suitable due to high viscosity but the same can be reduced by refining castor oil prior to transesterification. The study also reveals that neutralization of oils generally improves the quality of biodiesel by lowering the amount of free fatty acids and thus increasing yield. Ganeshan and Elango (2013) have investigated the performance of compression ignition engine for different blends of castor oil biodiesel and ethanol. The experiment was conducted on single cylinder Compression Ignition engine, the result obtained for a blend with $70 \%$ diesel, $10 \%$ castor oil and $20 \%$ ethanol gives optimum values of performance and also shown decrease in NOx and unburnt hydrocarbon emissions. In this study results obtained by experiment are compared with the one obtained computational fluid dynamics and are found to be in great accuracy. Wilson and Yalini (2015) have investigated the performance and emission characteristics of CI engine using multiple blends of castor oil in single cylinder four stroke compression ignition engine at different load conditions with different shapes of piston. In this study the castor oil biofuel is produced in two stage process, first being acid catalyzed esterification to reduce free fatty acid content below $1 \%$, the next is base catalyzed transesterification to convert oil to biodiesel and resulted in $90 \%$ yield rate. Experiment have been conducted with different proportions based on volume basis B100, B15, B35 and B45, the results are compared with the one obtained for diesel. The investigation reported that methyl ester of castor oil gives better performance when blended with diesel for toroidal shapes of piston. It is also observed that for the same piston shape specific fuel consumption and power obtained is maximum. Deshpande et al. (2012) have studied the method of production of castor oil biodiesel use acid and base catalyst. 
In this work the base and acid catalyst used are sodium hydroxide $(\mathrm{NaOH})$ and Sulfuric acid $\left(\mathrm{H}_{2} \mathrm{SO}_{4}\right.$ ), the influence of process parameters such as temperature, residue time, and catalyst concentration on yield are also presented. The results shows that with sulfuric acid as catalyst with increase in reaction time from 30 minutes to 45 minutes resulted in decrease in viscosity from $16.56 \mathrm{cSt}$ to $11.28 \mathrm{cSt}$ and further it observed that there is an increase in viscosity with increase in reaction time and optimum reaction temperature was found to be $55^{\circ} \mathrm{C} . \mathrm{By}$ using $\mathrm{NaOH}$ as catalyst, with increase in reaction time from 30 minutes to 45 minutes results in decrease in viscosity from 21.57 cSt to $13.10 \mathrm{cSt}$ and optimum reaction temperature was found to be $30^{\circ} \mathrm{C}$ which results in castor oil with lowest viscosity. Sreenivas et al. (2011) have studied the process of production of castor oil methyl esters in the presence of methanol and $\mathrm{NaOH}$ catalyst. The properties of produced biofuel were evaluated and found to be comparison with diesel as per ASTM and Indian biofuel standards. The fuel is biodegradable, non-toxic, high flash point and hence safe for transportation and storage. Higher cetane number is achieved hence increases combustion efficiency and decreases emissions.

\section{Injector opening pressure}

Injector opening pressure and injection timing significantly influence the performance and emission characteristics of IC engines and in past it was reported by many researchers, some are discussed here. Dharmadhikari et al. (2012) have evaluated the performance and emission characteristics of compressed ignition engine using blends of biodiesel and diesel at different injection pressure. In the present work neem oil methyl ester (NOME) and karanja oil methyl ester (KOME) are blended with diesel. The experiments are conducted for injection pressure (IP) range from 180 to 220 bar and 200 bar injection pressure was found to be the optimum value. For $\mathrm{B} 10$ and $\mathrm{B} 20$ blend the $\mathrm{HC}, \mathrm{CO}$ emissions are found to be less compared to that of diesel. The brake thermal for all blends fall in the range of $6 \%$ less in comparison with diesel. Blends B10 and B20 exhibits higher values of brake specific fuel consumption at higher loads compared to that of diesel. Jindal et al. (2010) have investigated the influence of compression ratio $(16,17$ and 18) and injection pressure $(150,200$ and $250 \mathrm{bar})$ in direct injection (DI) diesel engine fueled with Jatropha methyl esters. The results shows the trend of decreasing brake specific fuel consumption with increase in brake thermal efficiency and increases with combined increase in compression ratio and injection pressure. Hydrocarbon, NOx, smoke opacity and exhaust gas temperature is found lower for all combinations of compression ratio and injection pressure in comparison with diesel with same operating parameters. The optimum combination of compression ratio and injection pressure was found to be 18 and 250 bar respectively. Balasubbramanian et al. (2009) have studied the effect of IOP (200, 220 and 240 bar) on performance, emission and combustion characteristics of DI diesel engine fueled with linseed oil methyl esters. It was found that optimum injection pressure was 240 bar which gives thermal efficiency almost equal to diesel with decreased carbon monoxide and unburnt hydrocarbon emissions but there is a slight increase in NOx emissions. Nwafor et al. (2000) have investigated the effect on performance of diesel engine fueled with rapeseed oil with advanced injection timing. In diesel cycle the fuel is injected some degrees before top dead centre into the hot compressed cylinder gas because combustion process initiated by self-ignition. Combustion delay and lag in burning is observed in engines that uses alternate fuels hence the advancement of the injection timing will compensate for the same. The optimum injection timing results in maximum power and occurred within $5^{\circ}$ crank angle after top dead centre, hence injection timing of fuel was $3.5^{\circ}$ advanced and the inconsistent behavior of the engine was perceived with further rise in the same (Panneerselvam et al., 2015).

From the literature review undertaken on the production of biofuel, effect of operating parameters and the factors influencing the performance and emissions, it is observed that the research on the methods to reduce the viscosity has got great potential. Different injector opening pressure (IOP), the combustion efficiency analysis by using variable nozzle geometry and different combustion chamber shapes has great influence on the performance and emission characteristics of engine hence research related to that has got great prominence. The objective of the present work is to investigate the influence of IOP and nozzle geometry on the engine output characteristics.

\section{DESCRIPTION}

\section{Materials Used}

Experiments are conducted on 4 stroke single cylinder engine fitted with hemispherical combustion chamber with varied engine pressure (210 bar to 260 bar) and different nozzle geometry and the performance and emission characteristics are evaluated.

Castor oil was purchased from the local industry and the properties of the same are evaluated and mentioned in Table 1. 
Table 1. Raw Castor Oil Properties

\begin{tabular}{cc}
\hline Properties & Castor oil Methyl esters \\
\hline Flash point & $320^{\circ} \mathrm{C}$ \\
\hline Fire point & $345^{\circ} \mathrm{C}$ \\
\hline Kinematic viscosity & $52 \mathrm{cSt}$. \\
\hline Density & $956 \mathrm{~kg} / \mathrm{m}^{3}$ \\
\hline
\end{tabular}

\begin{tabular}{|l|l|l|l|}
\hline $\mathrm{F}_{1}$ & Fuel flow rate sensor & $\mathrm{T}_{3}$ & T emperature of the calorimeter water inlet \\
\hline $\mathrm{F}_{2}$ & Air flow rate measuring sensor & $\mathrm{T}_{4}$ & T emperature of calorimeter outlet \\
\hline $\mathrm{F}_{3}$ & Flow rate to the jacket water measurement & $\mathrm{T}_{5}$ & Temperature of exhaust gas before calorimeter \\
\hline $\mathrm{F}_{4}$ & Water flow inlet to the calorimeter & $\mathrm{T}_{6}$ & Temperature of exhaust gas after calorimeter \\
\hline $\mathrm{T}_{1}$ & Water jacket inlet temperature & PT & Pressure sensor at combustion chamber \\
\hline $\mathrm{T}_{2}$ & Water jacket outlet temperature & Wt & Weight \\
\hline
\end{tabular}

F1

F2

Fuel

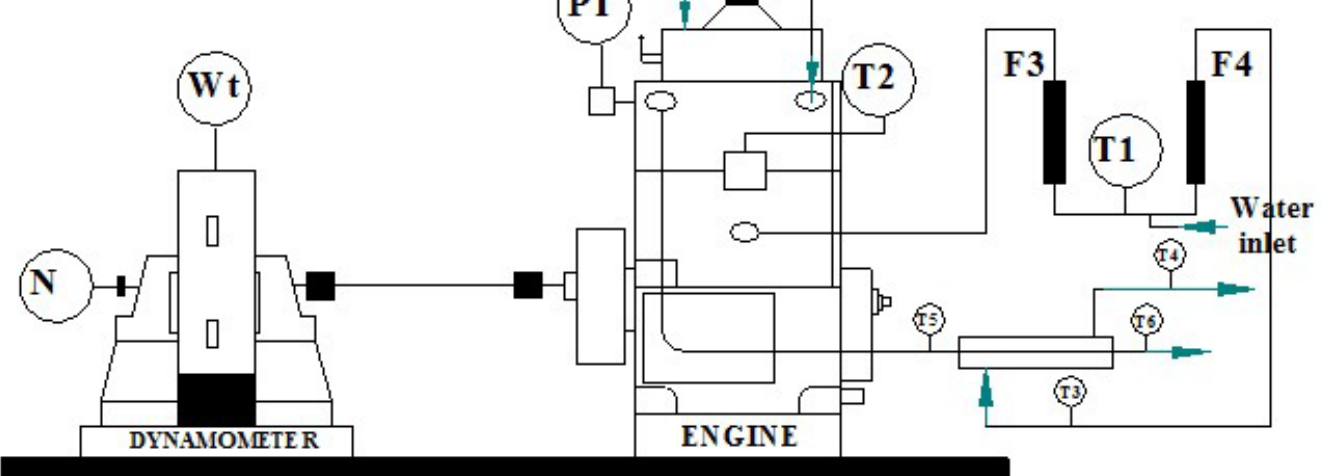

Figure 1. Schematic line diagram of engine test setup

Table 2. Properties of Biodiesel

\begin{tabular}{ccccccc}
\hline \multirow{2}{*}{$\begin{array}{c}\text { Diesel } \\
(\mathbf{\%})\end{array}$} & $\begin{array}{c}\text { Biodiesel (\%) } \\
\text { CAOME }\end{array}$ & $\begin{array}{c}\text { Density } \\
\left(\mathbf{k g} / \mathbf{m}^{\mathbf{3}}\right)\end{array}$ & $\begin{array}{c}\text { Viscosity } \\
(\mathbf{c S t})\end{array}$ & $\begin{array}{c}\text { Calorific Value } \\
(\mathbf{C V})(\mathbf{k J} / \mathbf{k g})\end{array}$ & $\begin{array}{c}\text { Specific } \\
\text { gravity }\end{array}$ & $\begin{array}{c}\text { Flash point } \\
\left(\mathbf{} \mathbf{}^{\circ} \mathbf{C}\right)\end{array}$ \\
\hline 100 & - & 834 & 2.38 & 42250 & 0.834 & 60 \\
\hline- & 100 & 927 & 5.57 & 37730 & 0.927 & 189 \\
\hline
\end{tabular}

Table 3. Engine specifications of tested engine

\begin{tabular}{ll}
\hline Parameters & Specifications \\
\hline Engine type & TV1 (Kirloskar make) \\
\hline Software used & Engine soft \\
\hline Injector operating pressure & 200 to 225 bar \\
\hline Static injection time & $23^{\circ}$ BTDC \\
\hline Governor type & Centrifugal type Mechanical \\
\hline No of cylinders & Single cylinder \\
\hline No of strokes & 4 stroke \\
\hline Fuel oil & High Speed Diesel \\
\hline Rated power & $5.2 \mathrm{~kW}$ at $1500 \mathrm{rpm}$ \\
\hline Cylinder diameter (Bore) & $0.0875 \mathrm{~m}$ \\
\hline Stroke length & $0.11 \mathrm{~m}$ \\
\hline Ratio of compression & $17.5: 1$ \\
\hline
\end{tabular}

The biodiesel is obtained from raw castor oil by transesterification, the process of removing fatty acid content in the presence of catalyst to produce the ethyl ester or methyl esters. The properties of castor oil biofuel are evaluated as per ASTM standards (Subcommittee: D02.E0 2009) are mentioned in Table 2. 

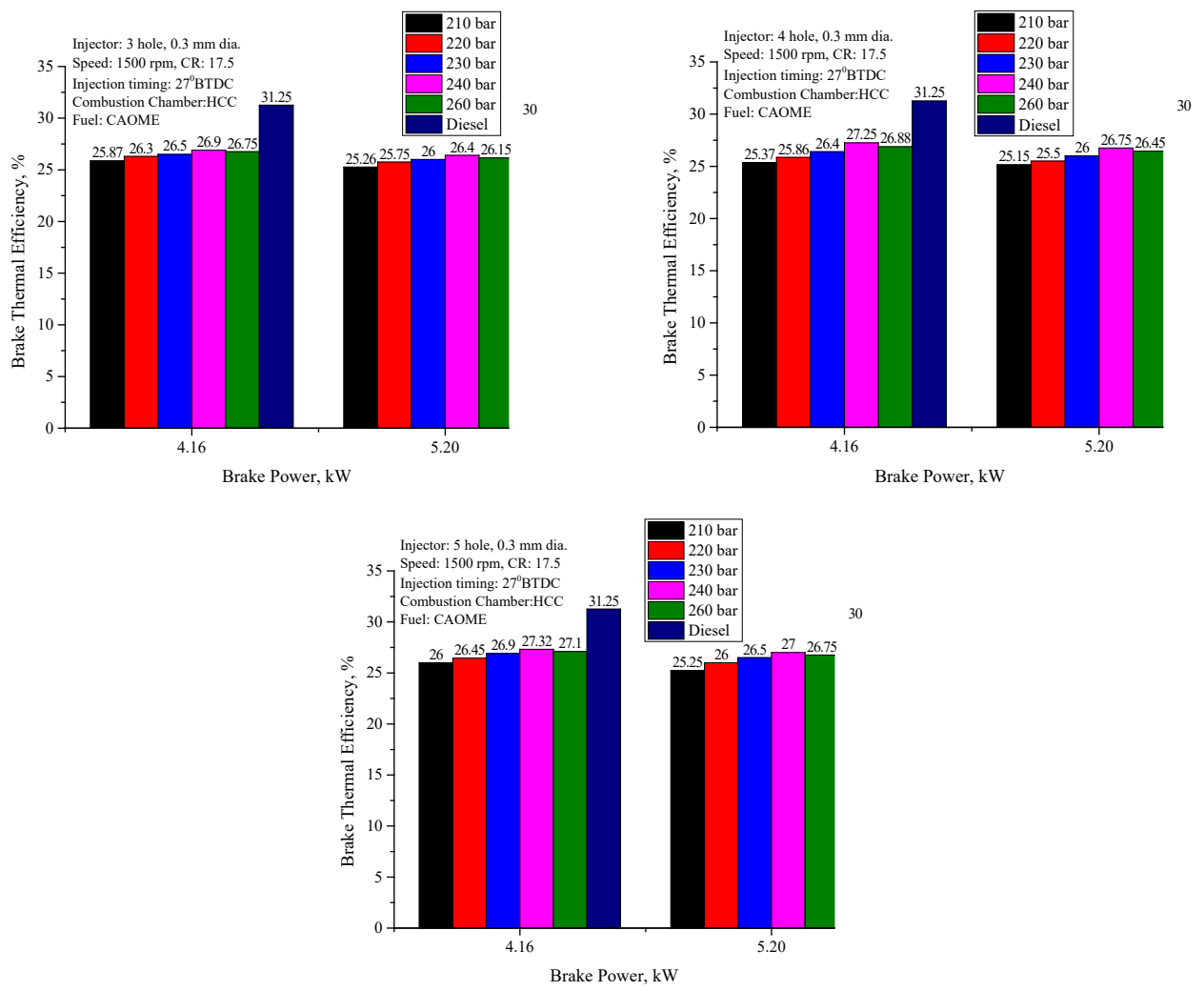

Figure 2. Brake Thermal Efficiency vs Brake power at different IOP

\section{EXPERIMENTAL RESULTS AND DISCUSSION}

\section{Optimization of Injector Opening Pressure (IOP) for Fuels Tested}

The research has been carried out to identify the optimum injector opening pressure and nozzle geometry on the biodiesel fueled modified diesel engine.

In the present work, studies on basic performance and emission characteristics of the engine were carried out on the normal diesel engine using CAOME at different injection pressures. The injector opening pressures were varied from 210 bar to $260 \mathrm{bar}$, for differential loading when the engine was running at $1500 \mathrm{rpm}$. Fuel and air flow rate, temperature of exhaust gas, Smoke, hydrocarbon $(\mathrm{HC})$, nitrogen oxides (NOx) and carbon monoxide (CO) emissions were chronicled. The optimum injection pressure is identified based on results and the same is fixed in the further work to evaluate engine performance, emissions and combustion parameters. For diesel mode the engine is operated as per manufacturer specification IOP of 205 bar. For 3, 4 and 5-hole ( $0.3 \mathrm{~mm}$ dia) nozzle and at an injection timing of $27^{\circ} \mathrm{BTDC}$ the effect of IOP in the range of $210 \mathrm{bar}$ to $260 \mathrm{bar}$ is presented in the following graphs.

\section{Effect of Nozzle Geometry and Injector Opening Pressure}

\section{Brake thermal efficiency}

For hemispherical combustion chamber at different IOP the effect of break power is shown in Figure 2 for different nozzle geometry. 240 bar injection pressure is found optimum as it resulted in highest brake thermal efficiency due to improved atomization, better spray characteristics and better mixing of fuel with air and which in turn improved combustion (Agarwal et al., 2014). Further rise in IOP (260 bar) results in injection delay and which in turn negates the gain of higher IOP's (Raeie et al., 2014). From the experimental results it is clearly observed that at 240 bar IOP higher thermal efficiency $(27.32 \%)$ is produced when the engine is fitted with 5-hole nozzle in comparison with 3 hole and 4-hole nozzles which is due to improved air-fuel mixing rate.

\section{Smoke opacity}

The smoke opacity for nozzle with 3, 4- and 5-hole nozzle for IOP ranging from 200 to 240 bar for brake power output is shown in Figure 3. The increase in IOP decreases the smoke level due to increased spray atomization which is a result of better air fuel mixture formation up to $240 \mathrm{bar}$ and further increase in IOP (260bar) resulted in delayed injection as result the smoke opacity upsurge is reported. It is also observed form Figure 3 that 

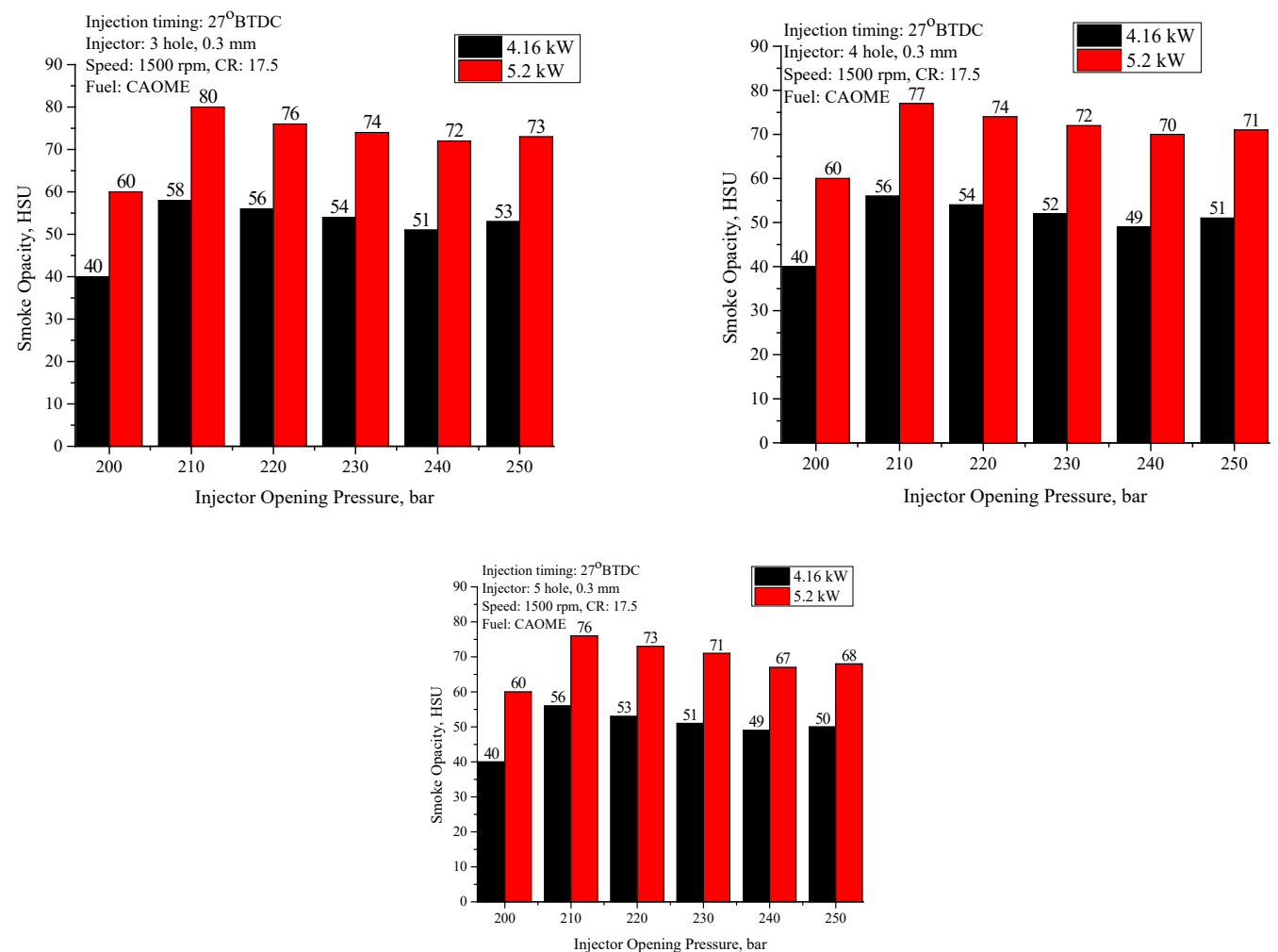

Figure 3. Smoke opacity v/s injector opening pressure for different nozzle geometry

the increase in number of holes in nozzle reduced the smoke emissions due to standardized air fuel mixture formation.

\section{HC emission}

It is perceived from Figure 4 that there is a substantial drop in $\mathrm{HC}$ emissions as a result of better combustion at 240 bar IOP. In general biofuels are higher viscous in comparison with diesel which will result in ignition delay but the higher IOP's compensate the ignition delay as a result of enhanced atomization (Das et al., 2018). Further increase in IOP $(260 \mathrm{bar})$ results in injection delay quashing the gain of higher IOP's. Better results are reported at 240 bar IOP for a 5 hole nozzle. 

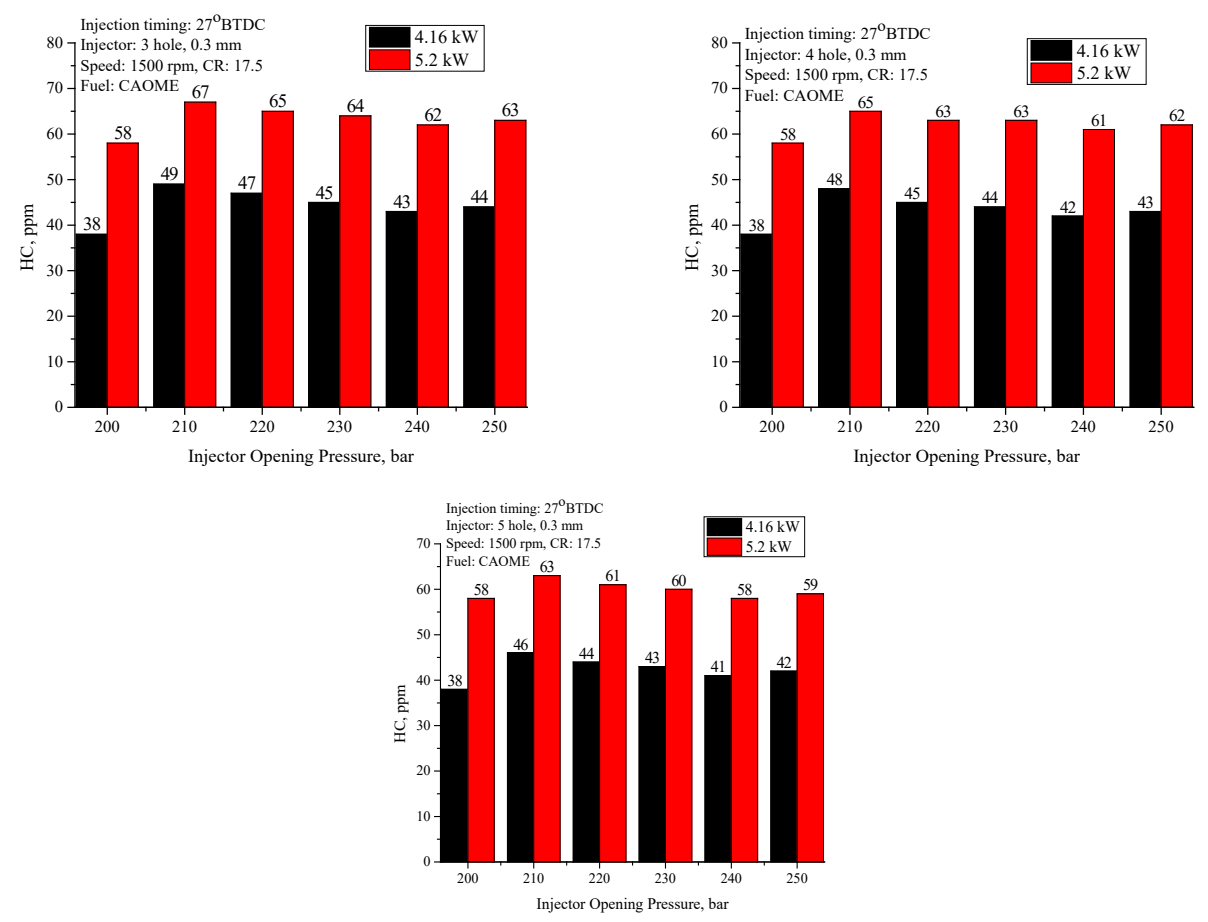

Figure 4. Unburned Hydrocarbon Emissions v/s injector opening pressure

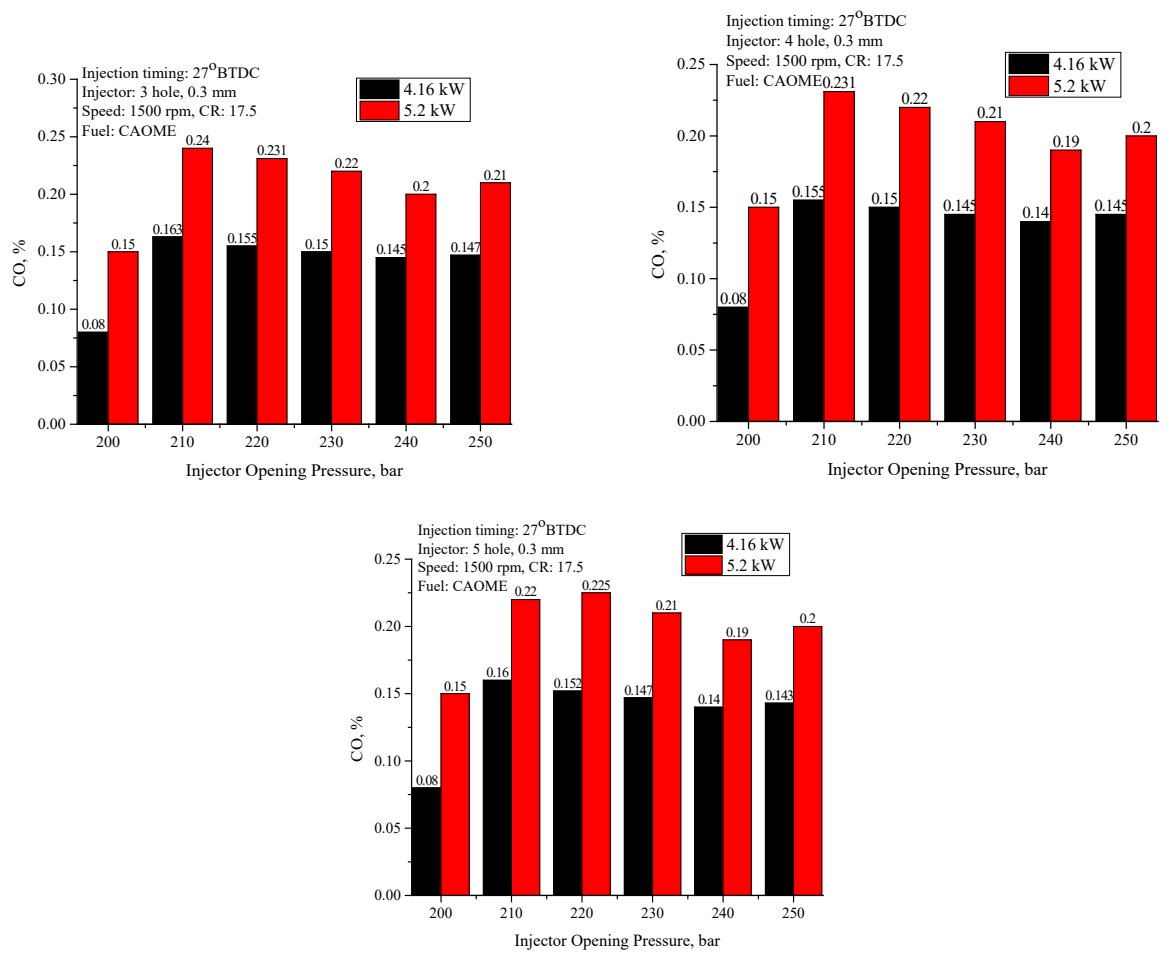

Figure 5. Carbon Monoxide Emissions v/s injector opening pressure

\section{CO emission}

Better combustion occurs at 240 bar IOP resulted in lower CO emissions which follows the similar trend as of HC emissions. Best results in terms of emissions are reported at 240 bar IOP for a 5 hole nozzle.

\section{NOx emission for different nozzle geometry}

Higher engine cylinder temperatures are reported due to enhanced combustion efficiency as result the upturn in nitric oxide emissions is observed, the peak values of the same are reported at 240 bar IOP for a 5-hole nozzle (Bueno et al., 2017). 


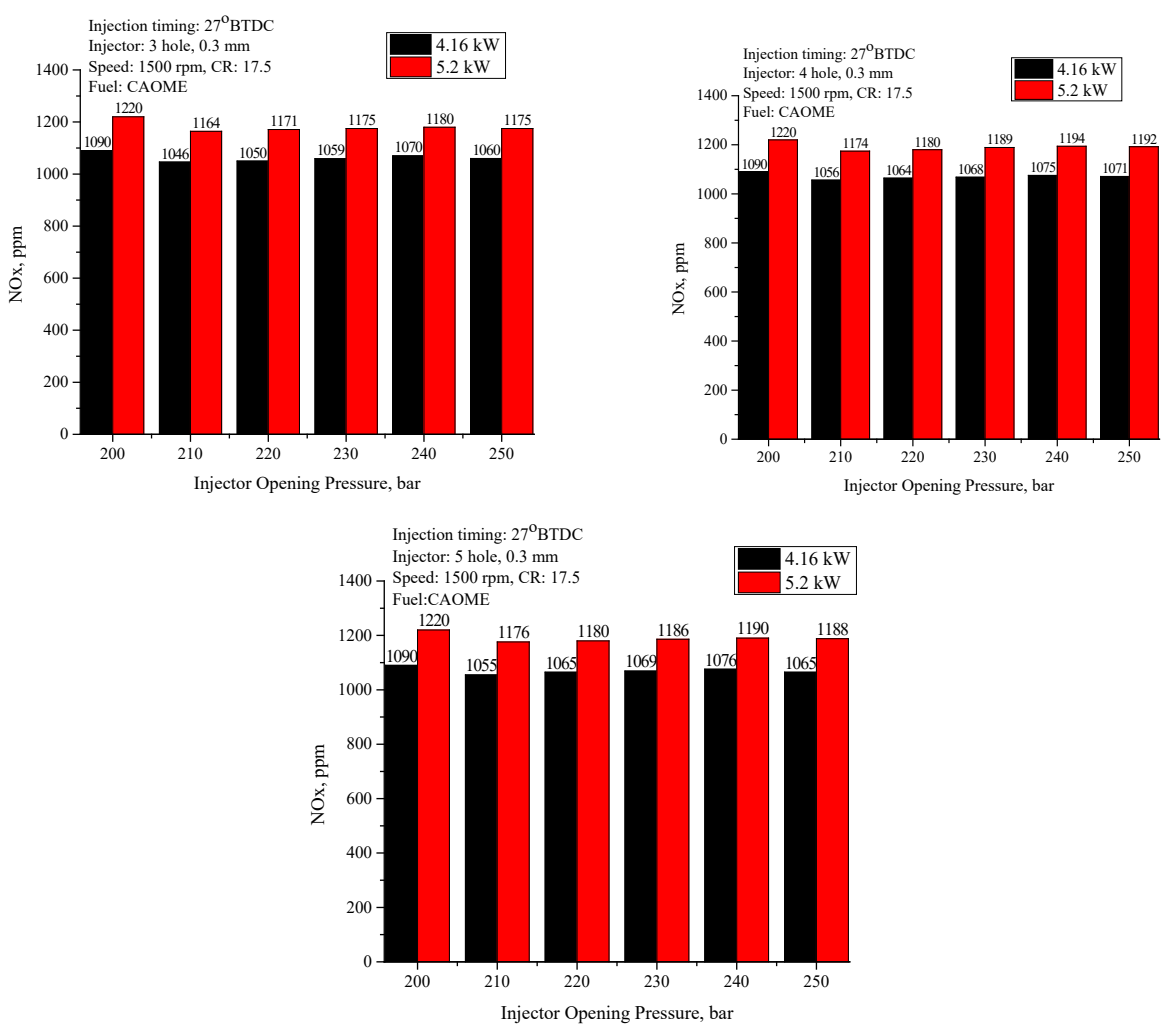

Figure 6. $\mathrm{NO}_{\mathrm{x}}$ Emissions v/s injector opening pressure

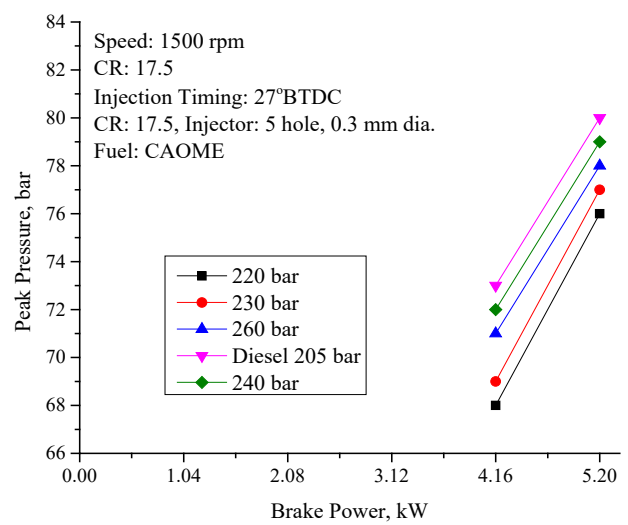

Figure 7. Peak Pressure v/s Brake power at different injector opening pressure

\section{Peak pressure with brake power}

The energy content and viscosity of CAOME is less in comparison with diesel hence lower peak pressure is observed due to ignition delay, slow burning rate, lower adiabatic flame temperature as a result of incomplete combustion due to improper mixing of fuel and air. Figure 7 shows substantial upturn in peak pressure with increase in IOP from 210 bar to 240 bar and further rise in IOP is adversely affected due to injection delay.

\section{Ignition delay period with brake power}

For a 5-hole nozzle the influence of Injector opening pressure on ignition delay with brake power for diesel and CAOME is illustrated in Figure 8. Static injection timing is taken as reference to calculate ignition delay, and it decreased with load and increased with biodiesel operation and the same is observed when the engine fuelled with CAOME. The delay in ignition can be compensated by increasing IOP which result in better combustion. 


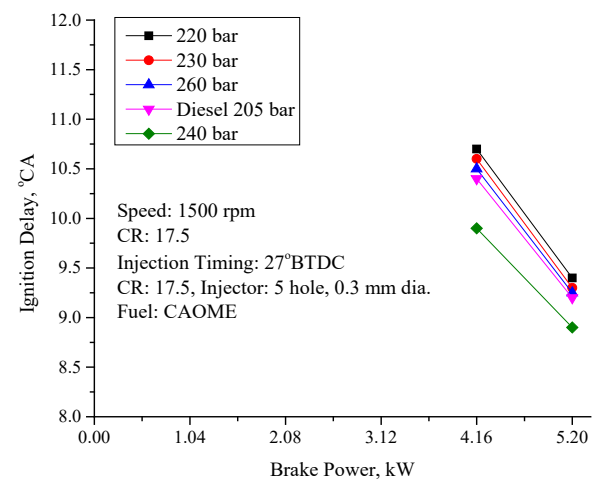

Figure 8. Ignition Delay Period v/s Brake Power for different injector opening pressure

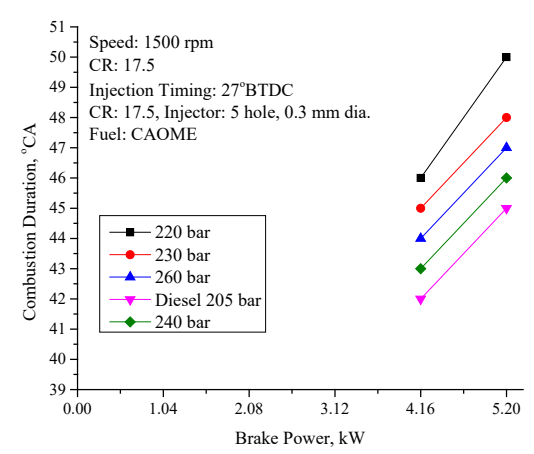

Figure 9. Combustion Duration v/s Brake Power for different injector opening pressure

\section{Combustion duration with brake power}

In the present context the Combustion duration is the time duration between combustion initiation and the time to release 90 percent heat content. It is observed from Figure 9 that there is a notable rise in combustion duration for both CAOME and diesel with increase in brake power and for IOP as well. CAOME combustion duration trends are higher in comparison with diesel due its viscous nature and less energy content and the same is up to certain extent is compensated by high IOP's.

\section{Limitations of the Work}

In the present work experiments are conducted on engine fitted with hemispherical combustion chamber. The experiments can be conducted by varying injection timing in engine fitted with different combustion chambers such as toroidal and reverse toroidal other than manufacturer specifications and influence of the same can be evaluated.

\section{Conclusion}

For a hemispherical combustion chamber, adopting 240 bar injection pressure for a five-hole nozzle is found optimum as it resulted in highest brake thermal efficiency $(27.32 \%)$ due to improved atomization, better spray characteristics and better mixing of fuel with air and which in turn improved combustion. Gradual decrease in Smoke level, unburnt HC and CO emissions are observed with increased in IOP from 210 to 240 bar. Further rise in IOP (260 bar) results in injection delay and which in turn negates the gain of higher IOP's. The peak value of pressure is 79 bar at IOP of 240 bar and there is a substantial upturn in peak pressure with increase in IOP from 210 bar to 240 bar and further rise in IOP is adversely affected due to injection delay.

Among all IOP and nozzles tested, the best results in terms higher power and less emissions are found for 5hole nozzle and at 240 bar IOP and the same is observed with increase in number of holes in the nozzle. 


\section{REFERENCES}

Aboelazayem, O., El-Gendy, N. Sh., Abdel-Rehim, A. A., Ashour, F. and Sadek, M. A. (2018). Biodiesel production from castor oil in Egypt: Process optimisation, kinetic study, diesel engine performance and exhaust emissions analysis. Energy, 157, 843e852. https://doi.org/10.1016/j.energy.2018.05.202

Abu-Elyazeed, O. S. M. (2015). On the ignition delay of two types of Castor oil bio-diesel using shock tube experiments. Fuel, 144, 157-163. https://doi.org/10.1016/j.fuel.2014.12.041

Agarwal, A. K., et al. (2014). Effect of fuel injection timing and pressure on combustion, emissions and performance characteristics of a single cylinder diesel engine. Fuel, 111, 374-383. https://doi.org/10.1016/j.fuel.2013.03.016

Arunkumar, M., Kannan, M. and Murali, G. (2019). Experimental studies on engine performance and emission characteristics using castor biodiesel as fuel in CI engine. Renewable Energy, 131, 737e 744. https://doi.org/10.1016/j.renene.2018.07.096

Attia, A. M. A., Nour, M. and Nada, S. A. (2018). Study of Egyptian castor biodiesel-diesel fuel properties and diesel engine performance for a wide range of blending ratios and operating conditions for the sake of the optimal blending ratio. Energy Conversion and Management, 174, 364-377. https://doi.org/10.1016/j.enconman.2018.08.016

Barajas Forero, C. L. (2005). Biodiesel from castor oil: a promising fuel for cold weather. The Renewable Energy \& Power Quality Journal, 1(3). https:/ / doi.org/10.24084/repqj03.222

Bari, S., Yu, C. W. and Lim, T. H. (2004). Effect of fuel injection timing with waste cooking oil as a fuel in a direct injection diesel engine. Proceedings of Institute Mechanical Engineering, Part D: Journal of Automotive Engineering, 218(1), 93-104. https://doi.org/10.1243/095440704322829209

Bueno, A. V., Bento Pereira, M. P., de Oliveira Pontes, J. V., de Luna, F. M. T. and Cavalcante Jr., C. L. (2017). Performance and emissions characteristics of castor oil biodiesel fuel blends. Applied Thermal Engineering, 125, 559-566. https://doi.org/10.1016/j.applthermaleng.2017.06.114

Das, M., Sarkar, M., Datta, A. and Santra, A. K. (2018). An experimental study on the combustion, performance and emission characteristics of a diesel engine fuelled with diesel-castor oil biodiesel blends. Renewable Energy, 119, 174e184. https://doi.org/10.1016/j.renene.2017.12.014

Dasari, S. R., Chaudhary, A. J., Goud, V. V., Sahoo, N. and Kulkarni, V. N. (2017). In-situ alkaline transesterification of castor seeds: Optimization and engine performance, combustion and emission characteristics of blends. Energy Conversion and Management, 142, 200-214. https://doi.org/10.1016/j.enconman.2017.03.044

Deshpande, D. P., Urunkar, Y. D. and Thakare P. D. (2012). Production of Biodiesel from Castor Oil using acid and Base catalysts. Research Journal of Chemical Sciences, 2(8), 51-56.

Drarmadhikari, H. M., Ravikumar, P. and Rao, S. S. (2012). Performance and Emissions of C.I. Engine Using Blends of Biodiesel and Diesel at Different Injection Pressures. International Journal of Applied Research in Mechanical Engineering (IJARME), 2(2).

Fadhil, A. B., Al-Tikrity, E. T. B. and Albadree, M. A. (2017). Biodiesel production from mixed non-edible oils, castor seed oil and waste fish oil. Fuel, 210, 721-728. https://doi.org/10.1016/j.fuel.2017.09.009

Ganapathy, T., Gakkhar, R. P. and Murugesan, K. (2011). Influence of injection timing on performance, combustion and emission characteristics of Jatropha biodiesel engine. Applied Energy, 88(12), 4376-4386. https://doi.org/10.1016/j.apenergy.2011.05.016

Ganesan, S. and Elango A. (2013). Performance Analysis of CI Engine using blends of Castor Oil and Ethanol. International Journal of Mining, Metallurgy \& Mechanical Engineering (IJMMME), 1(1).

Hajlari, S. A., Najafi, B. and Ardabili, S. F. (2019). Castor oil, a source for biodiesel production and its impact on the diesel engine performance. Renewable Energy Focus, 28(00). https://doi.org/10.1016/j.ref.2018.09.006

He, B.-Q. (2015). Advances in emission characteristics of diesel engines using different biodiesel fuels. Renewable and Sustainable Energy Reviews, 60, 570-586. https://doi.org/10.1016/j.rser.2016.01.093

Huang, W.-C., Hou, S.-S. and Lin, T.-H. (2017). Combustion characteristics of a $300 \mathrm{kWth}$ oil-fired furnace using castor oil/diesel blended fuels. Fuel, 208, 71-81. https://doi.org/10.1016/j.fuel.2017.07.007

Imankulov, N. (2012). Preparation and research on properties of castor oil as a diesel fuel additive. Applied Technologies and Innovations, 6(1), 30-37. https://doi.org/10.15208/ati.2012.4

Jaat, N., Khalid, A., Sapit, A., Rhaodah, A., Basharie, M. and Fawzi, M. (2016). The influences of injection pressure and Ambient temperature on ignition delay and emission. ARPN Journal of Engineering and Applied Sciences, 11(12).

Jiaqiang, E., Pham, M., Zhao, D., Deng, Y., Le, D., Zuo, W., Zhu, H., Liu, T., Peng, Q. and Zhang, Z. (2017). Effect of different technologies on combustion and emissions of the diesel engine fueled with biodiesel: A review. Renewable and Sustainable Energy Reviews, 80, 620-647. https://doi.org/10.1016/j.rser.2017.05.250 
Jindal, S., Nandwana, B. P., Rathore, N. S. and Vashistha, V. (2010). Experimental investigation of the effect of compression ratio and injection pressure in a direct injection diesel engine running on Jatropha methyl ester. Applied Thermal Engineering, 30(5), 442-448. https://doi.org/10.1016/j.applthermaleng.2009.10.004

Mani, M. and Nagarajan, G. (2009). Influence of injection timing on performance, emission and combustion characteristics of a DI diesel engine running on waste plastic oil. Energy, 34(10), 1617-1623. https://doi.org/10.1016/j.energy.2009.07.010

Nwafor, O. M. I., Rice, G. and Ogbonna, A. I. (2000). Effect of advanced injection timing on the performance of rapeseed oil in diesel engines. Renewable Energy, 21(3-4), 433-444. https://doi.org/10.1016/S09601481(00)00037-9

Okullo, A. and Temu, A. K. (2012). Physico-Chemical Properties of Biodiesel from Jatropha and Castor Oils. International Journal of Renewable Energy Research, 2(1).

Panneerselvam, N., Murugesan, A., Vijayakumar, C., Kumaravel, A., Subramaniam, D. and Avinash, A. (2015). Effects of injection timing on bio-diesel fueled engine characteristics-An overview. Renewable and Sustainable Energy Reviews, 50, 17-31. https://doi.org/10.1016/j.rser.2015.04.157

Panwar Hemant, N. L., Shrirame, Y., Rathore, N. S., Jindal, S. and Kurchania A. K. (2010). Performance evaluation of a diesel engine fueled with methyl ester of castor seed oil. Applied Thermal Engineering, 30, 245-249. https://doi.org/10.1016/j.applthermaleng.2009.07.007

Pinzi, S., López, I., Leiva-Candia, D. E., Redel-Macías, M. D., Herreros, J. M., Cubero-Atienza, A. and Dorado, M. P. (2018). Castor oil enhanced effect on fuel ethanol-diesel fuel blend properties. Applied Energy, 224, 409416. https://doi.org/10.1016/j.apenergy.2018.05.024

Puhan, S., Jegan, R., Balasubbramanian, K. and Nagarajan, G. (2009). Effect of injection pressure on performance, emission and combustion characteristics of high linolenic linseed oil methyl ester in a DI diesel engine. Renewable Energy, 34(5), 1227-1233. https:// doi.org/10.1016/j.renene.2008.10.001

Qi, D., Leick, M., Liu, Y. and Lee, C. F. (2011). Effect of EGR and injection timing on combustion and emission characteristics of split injection strategy DI-diesel engine fueled with biodiesel. Fuel, 90(5), 1884-1891. https://doi.org/10.1016/j.fuel.2011.01.016

Raeie, N., Emami, S. and Sadaghiyani, O. K. (2014). Effects of injection timing, before and after top dead center on the propulsion and power in a diesel engine. Propulsion and power research, 3(2), 59-67. https://doi.org/10.1016/j.jppr.2014.06.001

Rajak, U. and Verma, T. N. (2019). A comparative analysis of engine characteristics from various biodiesels: Numerical study. Energy Conversion and Management, 180, 904-923. https://doi.org/10.1016/j.enconman.2018.11.044

Reddy, S. M., Sharma, N., Gupta, N. and Agarwal, A. K. (2018). Effect of non-edible oil and its biodiesel on wear of fuel injection equipment components of a genset engine, Fuel, 222, 841-851. https://doi.org/10.1016/j.fuel.2018.02.132

Sreenivas, P., Mamilla, V. R., and Sekhar, K. C. (2011). Development of Biodiesel from Castor Oil. IJES, 1(3), $192-$ 197.

Subcommittee: D02.E0 (2009). Standard Specification for biodiesel (B100) Blend stock for Distillate Fuels. In Annual book of ASTM Standards, 1131-1136, west Conshohocken, PA: American society for testing and materials. d7651-02, 2009.

Wilson, V. H. and Yalini, V. (2015). An Experimental Investigation on The Performance Characteristic Of C.I Engine Using Multiple Blends of Methyl Castor Oil in Different Piston Shapes. (IJAER), 10(III). 